Key Words:

Tank 50

Waste Acceptance Criteria Saltstone

Retention:

Permanent

\title{
RESULTS FOR THE FIRST QUARTER 2009 \\ TANK 50 WAC SLURRY SAMPLE: \\ CHEMICAL AND RADIONUCLIDE CONTAMINANT RESULTS
}

\author{
Marissa M. Reigel \\ Cecilia C. DiPrete \\ Ned E. Bibler
}

OCTOBER 2009

Savannah River National Laboratory

Savannah River Nuclear Solutions

Aiken, SC 29808

Prepared for the U.S. Department of Energy Under

Contract Number DE-AC09-08SR22470 


\section{DISCLAIMER}

This work was prepared under an agreement with and funded by the U.S. Government. Neither the U. S. Government or its employees, nor any of its contractors, subcontractors or their employees, makes any express or implied:

1. warranty or assumes any legal liability for the accuracy, completeness, or for the use or results of such use of any information, product, or process disclosed; or

2. representation that such use or results of such use would not infringe privately owned rights; or

3. endorsement or recommendation of any specifically identified commercial product, process, or service.

Any views and opinions of authors expressed in this work do not necessarily state or reflect those of the United States Government, or its contractors, or subcontractors.

Printed in the United States of America

Prepared for

U.S. Department of Energy 
Key Words:

Tank 50

Waste Acceptance Criteria

Saltstone

Retention:

Permanent

\title{
RESULTS FOR THE FIRST QUARTER 2009 \\ TANK 50 WAC SLURRY SAMPLE: CHEMICAL AND RADIONUCLIDE CONTAMINANT RESULTS
}

\author{
Marissa M. Reigel \\ Cecilia C. DiPrete \\ Ned E. Bibler
}

OCTOBER 2009

Savannah River National Laboratory

Savannah River Nuclear Solutions

Aiken, SC 29808 


\section{REVIEWS AND APPROVALS}

\section{AUTHORS:}

Marissa M. Reigel, Engineering Process Development

Date

Cecilia C. DiPrete, Analytical Development

Date

Ned E. Bibler, Process Technology Programs

Date

\section{TECHNICAL REVIEWERS:}

Alex D. Cozzi, Engineering Process Development

Date

Kristine E. Zeigler, Manager, Material Performance \& Corrosion Technology

Date

\section{APPROVERS:}

John E. Occhipinti, Manager, Waste Solidification Engineering

Date

Arthur W. (Skip) Wiggins, LWO Process Chemistry

Date

Lori M. Chandler, Manager, Analytical Development

Date

Sharon L. Marra, Manager, E \& CPT Research Programs

Date

Allan B. Barnes, Manager, Engineering Process Development

Date 


\section{TABLE OF CONTENTS}

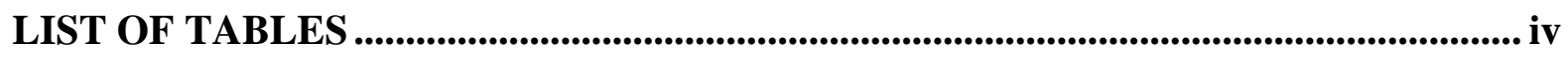

LIST OF ACRONYMS AND ABBREVIATIONS .................................................. v

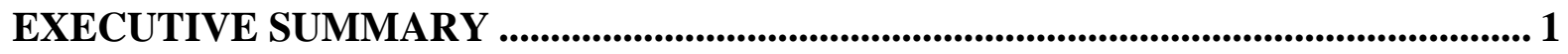

1.0 INTRODUCTION AND BACKGROUND....................................................... 2

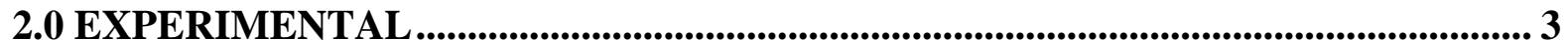

3.0 RESULTS AND DISCUSSION .......................................................................... 5

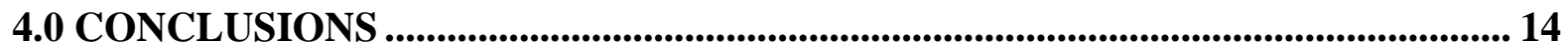

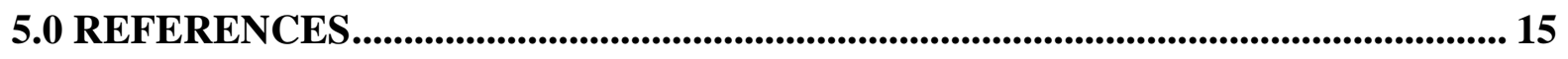

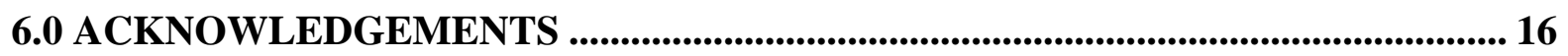




\section{LIST OF TABLES}

Table 3-1. Results for the 1st Quarter 2009 Tank 50 Slurry Samples for Chemical

Contaminants Listed in Attachment 8.1 of the Saltstone WAC..................................... 6

Table 3-2. Results for the 1st Quarter 2009 Tank 50 Slurry Samples for Chemical Contaminants Listed in Attachment 8.2 of the Saltstone WAC........................................ 7

Table 3-3. Results for 1st Quarter 2009 Tank 50 Slurry Samples and WAC Limits for Radionuclide Contaminants Listed in Attachment 8.3 of the Saltstone WAC. 8

Table 3-4. Results for 1st Quarter 2009 Tank 50 Slurry Samples and WAC Targets for Radionuclide Contaminants Listed in Attachment 8.4 of the Saltstone WAC.

Table 3-5. Results for the 1st Quarter 2009 Tank 50 Slurry Samples for Acceptance Criteria Limits for Chemical Contaminants Impacting Vault Flammability, Listed in Table 3 of the Saltstone WAC.

Table 3-6. Results for the 1st Quarter 2009 Tank 50 Slurry Samples for Concentrations of “Other Organics” Impacting Vault Flammability, Listed in Table 4 of the Saltstone WAC.

Table 3-7. Results for the 1st Quarter 2009 Tank 50 Slurry Samples for Saltstone Processing Criteria WAC Limits, Listed in Table 5 of the Saltstone WAC.

Table 3-8. Requests for Constituents for TCLP/UHC Support as well as from the TTR for Tank 50 Slurry Samples; Results Not Contained in Previous Tables.

Table 3-9. Requests from the WSE for Corrosion Species from Tank 50 Slurry Samples;

Results Not Contained in Previous Tables. 13 


\section{LIST OF ACRONYMS AND ABBREVIATIONS}

\begin{tabular}{|c|c|}
\hline $\mathrm{AD}$ & Analytical Development \\
\hline AA & Atomic Absorption (spectroscopy) \\
\hline ARP/MCU & Actinide Removal Process/Modular CSSX Unit \\
\hline CLFL & Composite Lower Flammability Limit \\
\hline DDA & Deliquification, Dissolution, and Adjustment \\
\hline ETP & Effluent Treatment Project \\
\hline GC/MS & Gas Chromatograph/Mass Spectrometer \\
\hline HDPE & High Density Polyethylene \\
\hline HPLC & High Performance Liquid Chromatography \\
\hline IC & Ion Chromatography \\
\hline ICP-ES & Inductively coupled plasma - (atomic) emission spectroscopy \\
\hline ICP-MS & Inductively coupled plasma - mass spectroscopy \\
\hline $\mathrm{L}$ & Liter \\
\hline LLW & Low Level Waste \\
\hline LSC & Liquid Scintillation Counting \\
\hline LWO & Liquid Waste Operations \\
\hline MDL & Method detection Limit \\
\hline MRL & Method Reporting Limit \\
\hline $\mathrm{mg}$ & Milligram \\
\hline $\mathrm{mL}$ & Milliliter \\
\hline ND & Not determined \\
\hline $\mathrm{pCi} / \mathrm{mL}$ & picocurie per milliliter \\
\hline RSD & Relative standard deviation \\
\hline SC & Shielded Cells (Facility) \\
\hline SDF & Saltstone Disposal Facility \\
\hline SFT & Salt Feed Tank \\
\hline SPF & Saltstone Production Facility \\
\hline SRNL & Savannah River National Laboratory \\
\hline SRS & Savannah River Site \\
\hline SVOA & Semi-volatile organic analysis \\
\hline TCLP/UHC & $\begin{array}{l}\text { Toxic Characterization Leaching Procedure/Underlying Hazardous } \\
\text { Constituent }\end{array}$ \\
\hline TIC/TOC & Total inorganic carbon/total organic carbon \\
\hline TTQAP & Task Technical and Quality Assurance Plan \\
\hline TTR & Technical Task Request \\
\hline VOA & Volatile organic analysis \\
\hline WAC & Waste Acceptance Criteria \\
\hline WCS & Waste Characterization System \\
\hline WSE & Waste Solidification Engineering \\
\hline WT \% & Weight percent \\
\hline
\end{tabular}




\section{EXECUTIVE SUMMARY}

This report details the chemical and radionuclide contaminant results for the characterization of the 2009 First Quarter sampling of Tank 50 for the Saltstone Waste Acceptance Criteria (WAC). ${ }^{1}$ Information from this characterization will be used by Liquid Waste Operations (LWO) to support the transfer of low-level aqueous waste from Tank 50 to the Salt Feed Tank in the Saltstone Facility in Z-Area, where the waste will be immobilized. This information is also used to update the Tank 50 Waste Characterization System.

The following conclusions are drawn from the analytical results provided in this report:

- The concentrations of the chemical and radioactive contaminants were all less than their respective WAC Targets or Limits except for Am-242m.

- The radionuclide Am-242m was not detected; however, its detection limit is above the WAC Target given in Attachment 8.4. The higher detection limit was expected based on current analytical capabilities as stated in the Task Technical and Quality Assurance Plan (TTQAP). ${ }^{3}$

- The reported detection limit of isopropanol was lower than its WAC Limit for accident analysis but higher than its WAC concentration given in Table 4 for vault flammability. The higher detection limit was expected based on current analytical capabilities and is documented in the Task Technical and Quality Assurance Plan (TTQAP). ${ }^{3}$

- The reported detection limit for Isopar L is lower than its WAC limit for accident analysis in Appendix 8.1 but higher than its WAC concentration given in Table 3 in reference to vault flammability. The higher detection limit was expected based on current analytical capabilities as stated in the Task Technical and Quality Assurance Plan (TTQAP). ${ }^{3}$

- Isopar L and Norpar 13 have limited solubility in aqueous solutions making it difficult to obtain consistent and reliable sub-samples. The values reported in this memo are the concentrations in the sub-sample as detected by the GC/MS; however, the results may not accurately represent the concentrations of these analytes in Tank 50. 


\subsection{INTRODUCTION AND BACKGROUND}

The Saltstone Facility is designed and permitted to immobilize and dispose of low-level radioactive and hazardous liquid waste (salt solution) remaining from the processing of radioactive material at the Savannah River Site. ${ }^{1}$ Low-activity wastewater streams from the Effluent Treatment Project (ETP), H-Canyon, the DDA (Deliquification, Dissolution, and Adjustment) process, and the decontaminated salt solution product from the Actinide Removal Process/Modular CSSX Unit (ARP/MCU) process are stored in Tank 50 until it can be transferred to the Saltstone Facility for treatment and disposal. The low-level aqueous waste (LLW) must meet the specified waste acceptance criteria (WAC) before it is processed into saltstone. ${ }^{1}$ The specific chemical and radionuclide contaminants and their respective WAC limits are listed in the current Saltstone WAC. ${ }^{1}$

SRS Liquid Waste Operations (LWO) solicited Savannah River National Laboratory (SRNL) to perform quarterly analysis on saltstone samples. ${ }^{2}$ The concentrations of chemical and radionuclide contaminants are measured to ensure the saltstone produced during each quarter is in compliance with the current WAC. ${ }^{1,3,4}$ This report documents the concentrations of chemical and radionuclide contaminants for the 2009 first quarter samples collected from Tank 50 on March 10, 2009 and discusses those results in further detail than the previously issued results report. ${ }^{5}$ 


\subsection{EXPERIMENTAL}

On March 10, 2009, one 3-L and one 200-mL sample (HTF-50-09-19 and HTF-50-09-17 respectively) were collected from Tank 50 for first quarter 2009 WAC analyses.

The 200-mL sample (HTF-50-09-17) was allowed to settle and duplicate samples ( 12 mL) of the supernate were transferred to glass vials with Teflon-lined caps. The vials were completely filled to minimize the void space and the volitization of organics. The aliquots were transferred to the Analytical Development (AD) Organic Analysis Laboratory to be analyzed for semi-volatile and volatile organic contaminants.

The 3-L sample (HTF-50-09-19) was mixed by recirculation using a peristaltic pump. After mixing/recirculating the slurry in the steel sampler for approximately 15 minutes, the slurry was transferred to a 4-L high density polyethylene (HDPE) bottle using the same pump. The transferred slurry was left undisturbed to settle overnight. The following day, a portion of the clear supernate was returned to the steel sampler, recirculated to mobilize any remaining solids, and again returned to the 4-L HDPE bottle. Visual inspection of the inside of the 3-L sampler indicated that all the solids had been removed. The weight of the transferred slurry was approximately 3600 grams.

The 4-L HDPE bottle was shaken to thoroughly mix the solids into the supernate. Aliquots of slurry samples were promptly collected with slurry pipettes to minimize settling effects. All samples (except those for volatile and semi-volatile organic analyses) were removed from the shielded cells (SC) in shielded bottles to reduce the beta dose rate of the samples.

Slurry samples were submitted in triplicate to $\mathrm{AD}$ laboratories for the following analyses:

- Six-mL aliquots to the AD Ion Chromatography (IC) Laboratory for soluble anion analyses and soluble cation analyses.

- Six-mL aliquots to the AD Organic Analysis Laboratory for measurement of tetraphenlyborate and ethylenediaminetetraacetic acid by high performance liquid chromatography (HPLC).

- Six-mL aliquots to the AD Wet Chemistry Laboratory for Total Inorganic Carbon/ Total Organic Carbon (TIC/TOC) analyses.

- Twelve-mL aliquots to the AD Dissolution Laboratory for digestion using an aqua regia method at $110{ }^{\circ} \mathrm{C}$. Visual inspection of the digestion indicated that all the solids had dissolved. Aliquots of dissolved slurries were then submitted to AD laboratories for inductively coupled plasma-(atomic) emission spectroscopy (ICPES), inductively coupled plasma-mass spectroscopy (ICP-MS), and atomic absorption spectroscopy (AA) for $\mathrm{Hg}$, As, K, Na, and Se.

- Twelve-mL aliquots to the AD Radiochemistry Laboratory for radiochemical separations and analyses. 
A 3-mL sample of the slurry was taken for determination of the density of the slurry.

Triplicate samples ( $\sim 6 \mathrm{~mL}$ each) of supernate were prepared by filtering aliquots of supernate using a 0.45 micron syringe filter. The filtered supernate samples were then submitted to the AD Wet Chemistry Laboratory for Total Base analyses. 


\subsection{RESULTS AND DISCUSSION}

The following tables contain the results for the 2009 first quarter WAC analyses. ${ }^{5}$ Each table provides the analyte of interest, the method used for measuring that analyte, the average concentration of the analyte based on triplicate samples (unless otherwise noted), the \%RSD of the average, and, if applicable, the WAC target or limit for the analyte concentration. Several of the contaminants were either not detected in the slurry samples or detected at values below the method reporting limit (MRL). For those analytes, the result is preceded by a " $<$ " which indicates the result is an upper limit based on the sensitivity of the method used to analyze the individual analyte.

Table 3-1, Table 3-2, Table 3-3, and Table 3-4 are based directly on attachments 8.1, 8.2, 8.3, and 8.4 , respectively, of the WAC. 
Table 3-1. Results for the 1st Quarter 2009 Tank 50 Slurry Samples for Chemical Contaminants Listed in Attachment 8.1 of the Saltstone WAC.

\begin{tabular}{|c|c|c|c|c|}
\hline Chemical Name & $\underline{\text { Method }}$ & $\frac{\text { Average Concentration }}{(\mathrm{mg} / \mathrm{L})}$ & \% RSD & $\frac{\text { WAC Limit }}{(\mathrm{mg} / \mathrm{L})}$ \\
\hline Ammonium $\left(\mathrm{NH}_{4}{ }^{+}\right)$ & $\mathrm{IC}$ & $<5.00 \mathrm{E}+01$ & - & $7.13 E+03$ \\
\hline Carbonate $\left(\mathrm{CO}_{3}{ }^{-2}\right)$ & TIC & $8.63 \mathrm{E}+03^{\mathrm{a}}$ & 2.03 & $1.45 E+05$ \\
\hline Chloride $\left(\mathrm{Cl}^{-}\right)$ & IC & $<1.25 \mathrm{E}+02$ & -- & $9.68 \mathrm{E}+03$ \\
\hline Fluoride (F') & IC & $<1.25 \mathrm{E}+02$ & - & $4.94 E+03$ \\
\hline Free Hydroxide $\left(\mathrm{OH}^{-}\right)$ & Total base & $1.75 \mathrm{E}+04^{\mathrm{b}}$ & 1.49 & $1.91 \mathrm{E}+05$ \\
\hline Nitrate $\left(\mathrm{NO}_{3}{ }^{-}\right)$ & $\mathrm{IC}$ & $1.10 \mathrm{E}+05$ & 3.66 & $5.29 \mathrm{E}+05$ \\
\hline Nitrite $\left(\mathrm{NO}_{2}{ }^{-}\right)$ & IC & $6.56 \mathrm{E}+03$ & 1.25 & $2.59 \mathrm{E}+05$ \\
\hline Oxalate $\left(\mathrm{C}_{2} \mathrm{O}_{4}^{-2}\right)$ & IC & $1.29 \mathrm{E}+03$ & 2.80 & $3.30 \mathrm{E}+04$ \\
\hline Phosphate $\left(\mathrm{PO}_{4}^{-3}\right)$ & ICP-ES & $6.42 \mathrm{E}+02$ & 3.46 & $3.56 E+04$ \\
\hline Sulfate $\left(\mathrm{SO}_{4}{ }^{-2}\right)$ & $\mathrm{IC}$ & $5.46 \mathrm{E}+03$ & 3.15 & $6.89 E+04$ \\
\hline Arsenic (As) & AA & $<1.05 \mathrm{E}-01$ & -- & $7.50 \mathrm{E}+02$ \\
\hline Barium (Ba) & ICP-ES & $4.58 \mathrm{E}-01$ & 8.93 & $7.50 \mathrm{E}+02$ \\
\hline Cadmium (Cd) & ICP-ES & $<4.56 \mathrm{E}-01$ & -- & $3.75 E+02$ \\
\hline Chromium (Cr) & ICP-ES & $4.43 \mathrm{E}+01$ & 3.64 & $1.50 \mathrm{E}+03$ \\
\hline Lead (Pb) & ICP-MS & 4.89E-01 & 1.32 & $7.50 \mathrm{E}+02$ \\
\hline Mercury (Hg) & AA & $1.12 \mathrm{E}+01$ & 1.78 & $3.25 E+02$ \\
\hline Selenium (Se) & AA & $<2.11 \mathrm{E}-01$ & -- & $4.50 \mathrm{E}+02$ \\
\hline Silver (Ag) & ICP-ES & $<9.36 \mathrm{E}-01$ & -- & $7.50 \mathrm{E}+02$ \\
\hline Aluminum (Al) & ICP-ES & $4.07 \mathrm{E}+03$ & 0.67 & $1.41 \mathrm{E}+05$ \\
\hline Butanol \& Isobutanol & VOA & $<5.0 \mathrm{E}-01^{\mathrm{c}}$ & -- & $2.25 E+03$ \\
\hline Isopropanol & VOA & $<5.0 \mathrm{E}-01^{\mathrm{c}}$ & -- & $2.25 E+03$ \\
\hline Phenol & SVOA & $<1 \mathrm{E}-01^{\mathrm{c}}$ & -- & $7.50 \mathrm{E}+02$ \\
\hline Isopar $\mathbf{L}$ & SVOA & $<2.77 \mathrm{E}+01 \mathrm{ppm}^{\mathrm{c}, \mathrm{d}}$ & -- & 1.50E+02 ppm \\
\hline Total organic carbon & TOC & $4.77 \mathrm{E}+02^{\mathrm{a}}$ & 30.1 & $5.00 \mathrm{E}+03$ \\
\hline $\begin{array}{l}\text { Tetraphenylborate } \\
\text { (TPB anion) }\end{array}$ & HPLC & $<5 \mathrm{E}+00$ & -- & $7.50 \mathrm{E}+02$ \\
\hline
\end{tabular}

As indicated in Table 3-1, all of the contaminants are within the WAC limits. However, Isopar L and Norpar 13 (Table 3-2) have negligible solubility in aqueous solutions, which makes it difficult to obtain reliable sub-samples. The values reported in these tables are the concentrations as detected by the GC/MS but are not necessarily an accurate representation of the concentrations of these analytes in Tank 50. It should be noted the WAC limit indicated for Isopar $\mathrm{L}$ and isopropanol is in reference to an accident consequence analysis and varies from the limit for each analyte in the vault flammability study shown in Table 3-5 and Table 3-6 respectively. 
Table 3-2. Results for the 1st Quarter 2009 Tank 50 Slurry Samples for Chemical Contaminants Listed in Attachment 8.2 of the Saltstone WAC.

\begin{tabular}{|c|c|c|c|c|}
\hline Chemical Name & $\underline{\text { Method }}$ & $\frac{\text { Average Concentration }}{(\mathrm{mg} / \mathrm{L})}$ & \% RSD & $\frac{\text { WAC TARGET }}{(\mathrm{mg} / \mathrm{L})}$ \\
\hline Boron (B) & ICP-ES & $5.12 \mathrm{E}+00$ & 2.80 & $9.00 \mathrm{E}+02$ \\
\hline Cobalt (Co) & ICP-MS & 8.17E-02 & 10.5 & $9.00 \mathrm{E}+02$ \\
\hline Copper (Cu) & ICP-ES & $<1.15 \mathrm{E}+00$ & -- & $9.00 \mathrm{E}+02$ \\
\hline Iron (Fe) & ICP-ES & $1.80 \mathrm{E}+02$ & 3.97 & $6.00 \mathrm{E}+03$ \\
\hline Potassium (K) & $\mathrm{AA}$ & $1.32 \mathrm{E}+02$ & 3.42 & $3.67 \mathrm{E}+04$ \\
\hline Lithium (Li) & ICP-ES & $1.26 \mathrm{E}+00$ & 21.5 & $9.00 \mathrm{E}+02$ \\
\hline Manganese (Mn) & ICP-ES & $1.15 \mathrm{E}+02$ & 1.65 & $9.00 \mathrm{E}+02$ \\
\hline Molybdenum (Mo) & ICP-ES & $5.94 \mathrm{E}+01$ & 1.91 & $9.00 \mathrm{E}+02$ \\
\hline Nickel (Ni) & ICP-ES & $1.59 \mathrm{E}+01$ & 6.81 & $9.00 \mathrm{E}+02$ \\
\hline Silicon (Si) & ICP-ES & $9.49 \mathrm{E}+01$ & 1.71 & $1.29 \mathrm{E}+04$ \\
\hline Strontium (Sr) & ICP-ES & 5.31E-01 & 0.81 & $9.00 \mathrm{E}+02$ \\
\hline Zinc (Zn) & ICP-ES & $1.03 \mathrm{E}+01$ & 2.23 & $9.75 E+02$ \\
\hline Benzene & VOA & $<5.0 \mathrm{E}-01^{\mathrm{a}}$ & -- & $3.75 \mathrm{E}+02$ \\
\hline Methanol & VOA & $\mathrm{b}$ & & $2.25 \mathrm{E}+02$ \\
\hline Toluene & VOA & $<5.0 \mathrm{E}-01^{\mathrm{a}}$ & - & $3.75 \mathrm{E}+02$ \\
\hline $\begin{array}{l}\text { TributylPhosphate } \\
\text { (TBP) }\end{array}$ & SVOA & $<1 \mathrm{E}-01^{\mathrm{a}}$ & -- & $3.00 \mathrm{E}+02$ \\
\hline EDTA & HPLC & $<1.00 \mathrm{E}+02$ & -- & $3.75 \mathrm{E}+02$ \\
\hline Norpar 13 & SVOA & $<1 \mathrm{E}-01^{\mathrm{a}}$ & -- & 1.0E-01 \\
\hline
\end{tabular}

a. Measurement performed on duplicate samples rather than triplicate samples.

b. Currently, a routine method for detecting this species does not exist in AD.

As seen in Table 3-2, none of the chemical contaminants exceed the WAC limit or target.

None of the radionuclide contaminants in Table 3-3 exceed the WAC limit. The value for Total Alpha is the sum of all of the alpha emitting radionuclide contaminants: U-232, U-233, U-234, U-235, U-236, U-238, Ra-226, Th-229, Th-230, Th-232, Np-237, Pu-238, Pu239/240, Pu-242, Pu-244, Am-241, Am-242m, Am-243, Cm-242, Cm-244, and Cm-245. If the alpha emitting radionuclide contaminant was not detectable above the method detection limit (MDL) of activity, the MDL was used in the sum. The total alpha can also be obtained from liquid scintillation counting (LSC) of the digested slurry. However this method detects both total alpha and total beta. Therefore, the alpha result is biased due to interference from the beta activity. In this sample, the Cs- 137 beta activity determined by gamma counting was $1.73 \mathrm{E}+07 \mathrm{pCi} / \mathrm{mL}$ and the total beta from LSC was $1.82 \mathrm{E}+07 \mathrm{pCi} / \mathrm{mL}$ (Table 3-8), which is higher than the Cs-137 measured by gamma counting. The Cs-137 activity is high enough to interfere with the alpha counting, resulting in a high bias result for the alpha counting. It is recommended that for future samples the liquid scintillation counting (LSC) of digested samples be performed after the cesium has been removed from the sample. 
Table 3-3. Results for 1st Quarter 2009 Tank 50 Slurry Samples and WAC Limits for Radionuclide Contaminants Listed in Attachment 8.3 of the Saltstone WAC.

\begin{tabular}{|c|c|c|c|c|}
\hline Radionuclide & Method & $\begin{array}{c}\frac{\text { Average }}{\text { Concentration }} \\
\frac{(\mathrm{pCi} / \mathrm{mL})}{}\end{array}$ & \% RSD & $\frac{\text { WAC LIMIT }}{(\mathbf{p C i} / \mathbf{m L})}$ \\
\hline Tritium $\left({ }^{3} \mathbf{H}\right)$ & Tritium counting & $7.64 \mathrm{E}+02^{\mathrm{a}}$ & $\mathrm{a}$ & $5.63 E+05$ \\
\hline Carbon-14 $\left({ }^{14} \mathrm{C}\right)$ & C-14 Liquid scintillation & $3.01 \mathrm{E}+02$ & 22.6 & $1.13 E+05$ \\
\hline Nickel-63 ( $\left.{ }^{63} \mathrm{Ni}\right)$ & Ni 59/63 & $1.07 \mathrm{E}+02$ & 3.66 & $1.13 E+05$ \\
\hline Strontium-90 ( $\left.{ }^{90} \mathrm{Sr}\right)$ & Sr-90 Liquid scintillation & $1.69 \mathrm{E}+05$ & 11.1 & $2.25 E+07$ \\
\hline Technetium-99 $\left({ }^{99} \mathrm{Tc}\right)$ & Tc-99 Liquid scintillation & $2.75 E+04$ & 2.73 & $4.22 E+05$ \\
\hline Iodine-129 $\left({ }^{129} \mathrm{I}\right)$ & $\begin{array}{c}\text { I-129 (w/ separation) } \\
\text { Liquid scintillation }\end{array}$ & $<1.96 \mathrm{E}+00$ & -- & $1.13 E+03$ \\
\hline Cesium-137 ( $\left.{ }^{137} \mathrm{Cs}\right)$ & Gamma Scan & $1.73 \mathrm{E}+07$ & 0.52 & $4.75 E+07$ \\
\hline Uranium-233 $\left({ }^{233} \mathrm{U}\right)$ & ICP-MS & $<4.64 \mathrm{E}+01$ & -- & $1.13 E+04$ \\
\hline Uranium-235 $\left({ }^{235} \mathrm{U}\right)$ & ICP-MS & $2.35 \mathrm{E}-01$ & 3.34 & $1.13 E+02$ \\
\hline Plutonium-241 ( $\left.{ }^{241} \mathrm{Pu}\right)$ & Pu238/241 Liquid scintillation & $<3.42 \mathrm{E}+03$ & -- & $8.38 \mathrm{E}+05$ \\
\hline Total Alpha & Calculated & $4.14 \mathrm{E}+04$ & -- & $2.50 \mathrm{E}+05$ \\
\hline
\end{tabular}

a. Result is from a single sample, the other two samples provided upper limit results due to interference.

As shown in Table 3-4, Am-242m is the only radionuclide contaminant that exceeds the WAC target. The reported detection limit for Am-242m is greater than the requested WAC limit $^{1}$ The value of Nb-93m in Table 3-4 is taken from the ICP-MS result for mass 93. The entire signal at mass 93 can be assigned to Zr-93, and since it is in secular equilibrium with $\mathrm{Nb}-93 \mathrm{~m}$ the maximum activity of the Nb-93m is equal to that of the Zr-93. Therefore the specific activity of Zr-93 (2.51E-03 Ci/g) is used when calculating the activity concentration of Nb-93m. The concentration of Cs-135 is calculated by assigning all of the mass at 135 to cesium. Sn-126 and Sb-126 are in secular equilibrium for this sample; therefore their activities are equal. As a result, the measured activity of Sb-126 was used for the Sn-126 concentration since Sb-126 was detected and Sn-126 was below the MDL. Since no analyte was detected at mass 229, and because the Th-229 and Th-230 isotopes have identical electronic structures, the MDL measured for Th-230 was used for the MDL for Th-229. The result for the mass of either isotope was $<2.31 \mathrm{E}-02 \mathrm{mg} / \mathrm{L}$. The activity concentrations are then calculated from the specific activities for Th-229 and Th-230. It is assumed all the mass detected at mass 244 is $\mathrm{Pu}-244$. For Pu-239/240, the value reported is the total mass of both $\mathrm{Pu}-239$ and for $\mathrm{Pu}-240$. This activity did not exceed the WAC limit for either isotope. 
Table 3-4. Results for 1st Quarter 2009 Tank 50 Slurry Samples and WAC Targets for Radionuclide Contaminants Listed in Attachment 8.4 of the Saltstone WAC.

\begin{tabular}{|c|c|c|c|c|}
\hline$\underline{\text { Radionuclide }}$ & Method & $\frac{\text { Average Concentration }}{(\mathbf{p C i} / \mathbf{m L})}$ & \%RSD & $\frac{\text { WAC }}{\text { TARGET }}$ \\
\hline Sodium-22 $\left({ }^{22} \mathrm{Na}\right)$ & $\begin{array}{l}\text { Gamma scan } \\
\text { (Cs removed) }\end{array}$ & $<1.41 \mathrm{E}+01$ & -- & $1.25 E+04$ \\
\hline Aluminum-26 $\left({ }^{26} \mathrm{Al}\right)$ & $\begin{array}{l}\text { Gamma scan } \\
\text { (Cs removed) }\end{array}$ & $<3.46 \mathrm{E}+00$ & -- & $2.88 E+03$ \\
\hline Cobalt-60 $\left({ }^{60} \mathrm{Co}\right)$ & $\begin{array}{l}\text { Gamma scan } \\
\text { (Cs removed) }\end{array}$ & $7.37 \mathrm{E}+00$ & 4.59 & $1.13 E+06$ \\
\hline Nickel-59 $\left({ }^{59} \mathrm{Ni}\right)$ & Ni59/63 & $<1.80 \mathrm{E}+01$ & -- & $1.13 E+05$ \\
\hline Selenium-79 $\left({ }^{79} \mathrm{Se}\right)$ & Se79 & $2.67 \mathrm{E}+02$ & 19.5 & $1.90 \mathrm{E}+04$ \\
\hline Niobium-93m $\left({ }^{93 \mathrm{~m}} \mathrm{Nb}\right)$ & ICP-MS & $4.14 \mathrm{E}+02$ & 2.30 & $2.85 \mathrm{E}+06$ \\
\hline Niobium-94 $\left({ }^{94} \mathrm{Nb}\right)$ & $\begin{array}{l}\text { Gamma scan } \\
\text { (Cs removed) }\end{array}$ & $<6.58 \mathrm{E}+00$ & -- & 1.53E+04 \\
\hline Molybdenum-93 ( $\left.{ }^{93} \mathrm{Mo}\right)$ & ICP-MS & $1.81 \mathrm{E}+05$ & 2.30 & $1.18 E+07$ \\
\hline Ruthenium-106 $\left({ }^{106} \mathrm{Ru}\right)$ & $\begin{array}{l}\text { Gamma scan } \\
\text { (Cs removed) }\end{array}$ & $<1.58 \mathrm{E}+02$ & -- & 1.13E+06 \\
\hline Antimony-125 $\left({ }^{125} \mathrm{Sb}\right)$ & $\begin{array}{l}\text { Gamma scan } \\
\text { (Cs removed) }\end{array}$ & $7.96 \mathrm{E}+03$ & 2.36 & $2.25 E+06$ \\
\hline Tin-126 $\left({ }^{126} \mathrm{Sn}\right)$ & $\begin{array}{c}\text { Gamma scan } \\
\text { (Cs removed, } \\
\text { Sb-126 } \\
\text { Counting) }\end{array}$ & $2.73 E+01$ & 5.68 & $1.80 \mathrm{E}+04$ \\
\hline Cesium-134 ( $\left.{ }^{134} \mathrm{Cs}\right)$ & Gamma Scan & $<5.45 \mathrm{E}+02$ & -- & $1.13 E+06$ \\
\hline Cesium-135 ( $\left.{ }^{135} \mathrm{Cs}\right)$ & ICP-MS & $1.16 \mathrm{E}+02$ & 3.11 & $1.13 E+06$ \\
\hline Cerium-144 ( $\left.{ }^{144} \mathrm{Ce}\right)$ & $\begin{array}{c}\text { Gamma scan } \\
\text { (Cs removed) }\end{array}$ & $<1.54 \mathrm{E}+02$ & -- & 1.13E+05 \\
\hline Promethium-147 ( $\left.{ }^{147} \mathrm{Pm}\right)$ & $\begin{array}{c}\text { Pm147/Sm151 } \\
\text { Liquid } \\
\text { scintillation } \\
\end{array}$ & $<3.11 \mathrm{E}+03$ & -- & $5.63 E+06$ \\
\hline Samarium-151 $\left({ }^{151} \mathrm{Sm}\right)$ & $\begin{array}{l}\text { Pm147/Sm151 } \\
\text { Liquid } \\
\text { scintillation }\end{array}$ & $<1.00 \mathrm{E}+03$ & -- & $2.25 E+04$ \\
\hline Europium-152 ( $\left.{ }^{152} \mathrm{Eu}\right)$ & $\begin{array}{l}\text { Gamma scan } \\
\text { (Cs removed) }\end{array}$ & $<1.96 \mathrm{E}+01$ & -- & $7.28 \mathrm{E}+01$ \\
\hline Europium-154 ( $\left({ }^{154} \mathrm{Eu}\right)$ & $\begin{array}{c}\text { Gamma scan } \\
\text { (Cs removed) }\end{array}$ & $2.13 \mathrm{E}+02$ & 1.82 & $2.25 E+06$ \\
\hline Europium-155 ( $\left.{ }^{155} \mathbf{E u}\right)$ & $\begin{array}{l}\text { Gamma scan } \\
\text { (Cs removed) }\end{array}$ & $<5.86 \mathrm{E}+01$ & -- & $1.13 E+04$ \\
\hline
\end{tabular}


Table 3-4 (continued). Results for 1st Quarter 2009 Tank 50 Slurry Samples and WAC Targets for Radionuclide Contaminants Listed in Attachment 8.4 of the Saltstone WAC.

\begin{tabular}{|c|c|c|c|c|}
\hline$\underline{\text { Radionuclide }}$ & $\underline{\text { Method }}$ & $\frac{\text { Average Concentration }}{(\mathrm{pCi} / \mathrm{mL})}$ & \%RSD & $\frac{\text { WAC }}{\text { TARGET }}$ \\
\hline Radium-226 ( ${ }^{226}$ Ra) & $\begin{array}{l}\text { Gamma scan } \\
\text { (Cs removed) }\end{array}$ & $<6.13 \mathrm{E}+02$ & -- & $7.97 \mathrm{E}+03$ \\
\hline Thorium-229 $\left({ }^{229} \mathrm{Th}\right)$ & ICP-MS & $<2.04 \mathrm{E}+03$ & -- & $1.63 E+05$ \\
\hline Thorium-230 $\left({ }^{230} \mathrm{Th}\right)$ & ICP-MS & $<2.02 \mathrm{E}+02$ & -- & $6.26 \mathrm{E}+03$ \\
\hline Thorium-232 ( $\left.{ }^{232} \mathrm{Th}\right)$ & ICP-MS & $9.62 \mathrm{E}-03$ & 4.36 & $2.88 \mathrm{E}+03$ \\
\hline Uranium-232 $\left({ }^{232} \mathrm{U}\right)$ & U232 & $6.92 \mathrm{E}+00$ & 104 & $1.71 E+05$ \\
\hline Uranium-234 $\left({ }^{234} \mathrm{U}\right)$ & ICP-MS & $<1.05 \mathrm{E}+02$ & -- & $1.13 E+04$ \\
\hline Uranium-236 $\left({ }^{236} U\right)$ & ICP-MS & $1.13 \mathrm{E}+00$ & 21.9 & 1.13E+04 \\
\hline Uranium-238 $\left({ }^{238} \mathrm{U}\right)$ & ICP-MS & 7.05E-01 & 1.28 & $1.13 E+04$ \\
\hline Neptunium-237 ( $\left.{ }^{237} \mathrm{~Np}\right)$ & ICP-MS & $1.09 \mathrm{E}+01$ & 15.4 & $2.50 \mathrm{E}+05$ \\
\hline Plutonium-238 ( $\left.{ }^{238} \mathrm{Pu}\right)$ & $\begin{array}{c}\text { Pu238/241 } \\
\text { Pu alpha PHA }\end{array}$ & $1.67 \mathrm{E}+04$ & 6.09 & $2.50 \mathrm{E}+05$ \\
\hline Plutonium-239 ( $\left.{ }^{239} \mathbf{P u}\right)$ & $\begin{array}{c}\mathrm{Pu} 238 / 241 \\
\mathrm{Pu} \text { alpha PHA }\end{array}$ & $5.77 \mathrm{E}+02$ & 10.2 & $2.50 \mathrm{E}+05$ \\
\hline Plutonium-240 ( $\left.{ }^{240} \mathrm{Pu}\right)$ & $\begin{array}{c}\text { Pu238/241 } \\
\text { Pu alpha PHA }\end{array}$ & $5.77 \mathrm{E}+02$ & 10.2 & $2.50 \mathrm{E}+05$ \\
\hline Plutonium-242 ( $\left.{ }^{242} \mathrm{Pu}\right)$ & ICP-MS & $<3.66 \mathrm{E}+01$ & -- & $2.50 \mathrm{E}+05$ \\
\hline Plutonium-244 ( $\left.{ }^{244} \mathrm{Pu}\right)$ & ICP-MS & $<8.50 \mathrm{E}-02$ & -- & $7.02 E+04$ \\
\hline Americium-241 ( $\left.{ }^{241} \mathrm{Am}\right)$ & $\begin{array}{l}\text { Gamma scan } \\
\text { (Cs removed) }\end{array}$ & $7.96 \mathrm{E}+02$ & 2.85 & $2.50 \mathrm{E}+05$ \\
\hline Americium-242m ( $\left.{ }^{242 m} \mathrm{Am}\right)$ & $\mathrm{Am} / \mathrm{Cm}$ & $<1.23 \mathrm{E}+00$ & -- & $3.68 \mathrm{E}-01$ \\
\hline Americium-243 ( $\left.{ }^{243} \mathrm{Am}\right)$ & $\mathrm{Am} / \mathrm{Cm}$ & $3.03 \mathrm{E}+01^{\mathrm{a}}$ & -- & $2.50 \mathrm{E}+05$ \\
\hline Curium-242 ( $\left.{ }^{242} \mathrm{Cm}\right)$ & $\mathrm{Am} / \mathrm{Cm}$ & $<1.01 \mathrm{E}+00$ & - & $1.13 E+04$ \\
\hline Curium-244 $\left({ }^{244} \mathrm{Cm}\right)$ & $\mathrm{Am} / \mathrm{Cm}$ & $1.73 \mathrm{E}+03$ & 27.0 & $2.50 \mathrm{E}+05$ \\
\hline Curium-245 $\left({ }^{245} \mathrm{Cm}\right)$ & $\mathrm{Am} / \mathrm{Cm}$ & $<1.09 \mathrm{E}+02$ & -- & $2.25 \mathrm{E}+05$ \\
\hline
\end{tabular}

a. Result is from a single sample, the remaining 2 samples had MDA values. 
Tables 3-5 and 3-6 list the chemical contaminants that impact vault flammability. These chemicals must be monitored to ensure flammable gases do not contribute more than $10 \%$ of the Composite Lower Flammability Limit (CLFL). ${ }^{1}$

Table 3-5. Results for the 1st Quarter 2009 Tank 50 Slurry Samples for Acceptance Criteria Limits for Chemical Contaminants Impacting Vault Flammability, Listed in Table 3 of the Saltstone WAC.

\begin{tabular}{|l|c|c|c|c|}
\hline Chemical Name & Method & $\frac{\begin{array}{c}\text { Average } \\
\text { Concentration }\end{array}}{\mathbf{( m g / L )}}$ & \% RSD & \multirow{2}{*}{ WAC Limit } \\
\hline Isopar L & SVOA & $<2.77 \mathrm{E}+01 \mathrm{ppm}^{\mathrm{a}}$ & -- & $\mathbf{1 . 1 0 E}+\mathbf{0 1} \mathbf{~ p p m}$ \\
\hline $\begin{array}{l}\text { Tetraphenylborate } \\
\text { (TPB anion) }\end{array}$ & HPLC & $<5.00 \mathrm{E}+00$ & -- & $\mathbf{5 . 0 0 E}+\mathbf{0 0} \mathbf{~ m g / L}$ \\
\hline Ammonium $\left(\mathbf{N H}_{\mathbf{4}}{ }^{+}\right)$ & IC & $<5.00 \mathrm{E}+01$ & -- & $\mathbf{2 . 1 2 E}+\mathbf{0 2} \mathbf{~ m g / L}$ \\
\hline
\end{tabular}

a. Result is calculated from the reported concentration of $<33 \mathrm{mg} / \mathrm{L}$ and the density of the slurry sample.

Table 3-6. Results for the 1st Quarter 2009 Tank 50 Slurry Samples for Concentrations of "Other Organics" Impacting Vault Flammability, Listed in Table 4 of the Saltstone WAC.

\begin{tabular}{|c|c|c|c|c|}
\hline Chemical Name & $\underline{\text { Method }}$ & $\begin{array}{c}\frac{\text { Average }}{\text { Concentration }} \\
\text { (mg/L) }\end{array}$ & \% RSD & $\begin{array}{c}\underline{\text { WAC }} \\
\underline{\text { Concentrations }}\end{array}$ \\
\hline Butanol & VOA & $<5.0 \mathrm{E}-01$ & -- & $0.75 \mathrm{mg} / \mathrm{L}$ \\
\hline Tributylphosphate & SVOA & $<1 \mathrm{E}-01$ & -- & $1.0 \mathrm{mg} / \mathrm{L}$ \\
\hline Isopropanol & VOA & $<5.0 \mathrm{E}-01$ & -- & $0.25 \mathrm{mg} / \mathrm{L}$ \\
\hline Methanol & $\mathrm{a}$ & $\mathrm{a}$ & & $0.25 \mathrm{mg} / \mathrm{L}$ \\
\hline Norpar 13 & SVOA & $<1 \mathrm{E}-01$ & -- & $0.1 \mathrm{mg} / \mathrm{L}$ \\
\hline
\end{tabular}

a. Currently, a routine method for detecting this species does not exist in AD.

None of the species considered in Tables 3-5 or 3-6 are above the WAC limit with the exception of isopropanol. As shown in Table 3-1, the concentration of isopropanol is below the WAC limit for the accident consequence analysis, but the detection limit is above the WAC limit for the vault flammability study shown in Table 3-6. ${ }^{1}$ The higher detection limit was expected per the TTQAP. ${ }^{3}$ As previously discussed, the insolubility of Isopar L and Norpar makes sub-sampling difficult, therefore the reported result is not necessarily representative of the concentration in Tank 50.

Table 3-7 provides results for the processing criteria for transfers into the Saltstone Facility. This table is based on Table 5 of the WAC. ${ }^{1}$ 
Table 3-7. Results for the 1st Quarter 2009 Tank 50 Slurry Samples for Saltstone Processing Criteria WAC Limits, Listed in Table 5 of the Saltstone WAC.

\begin{tabular}{|c|c|c|c|}
\hline Processing Criterion & Method & $\underline{\text { Value }}$ & \%RSD \\
\hline $\mathbf{p H}>\mathbf{1 0}$ & Calculated & $>13$ & 3.20 \\
\hline $\begin{array}{c}\mathbf{2 . 5} \mathbf{M}<\begin{array}{|}\left.\mathbf{N a}^{+}\right]<\mathbf{7 . 0} \\
\mathbf{M}\end{array} \\
\begin{array}{c}\text { Total Insoluble } \\
\text { Solids }<\mathbf{1 5} \mathbf{~ w t} \%\end{array}\end{array}$ & Calculated & $3.65 \mathrm{M}, \mathrm{AA}$ & 49 \\
\hline
\end{tabular}

All of the results contained in Table 3-7 fall within the general processing criteria. The $\mathrm{pH}$ was calculated using the free base concentration $\left(\mathrm{OH}^{-}\right)$. The value for the total insoluble solids was calculated by Engineering Process Development of SRNL from experimentally determined values for total solids and dissolved solids in the slurry supernate. ${ }^{7}$

Table 3-8 provides constituents listed in the TTR but are not contained in the WAC. The results are used in a series of calculations performed by the SRNL Engineering Process Development group to support TCLP/UHC testing by a certified laboratory. ${ }^{6}$ The density of the slurry was measured at $19.1^{\circ} \mathrm{C}$. Thallium was calculated by summing the ICP-MS results for masses of 203 and 205.

Table 3-8. Requests for Constituents for TCLP/UHC Support as well as from the TTR for Tank 50 Slurry Samples; Results Not Contained in Previous Tables.

\begin{tabular}{|l|c|c|c|}
\hline Constituent & Method & $\frac{\text { Average Concentration }}{\mathbf{( m g / L )}}$ & \%RSD \\
\hline Antimony (Sb) & ICP-ES & $<5.31 \mathrm{E}+00$ & -- \\
\hline Beryllium (Be) & ICP-ES & $<3.57 \mathrm{E}-02$ & - \\
\hline Cyanide (CN) & a. & a. & -- \\
\hline Thallium (Tl) & ICP-MS & $<2.15 \mathrm{E}-01$ & 0.01 \\
\hline Density (slurry) & Measured $\left(19.1^{\circ} \mathrm{C}\right)$ & $1.1898 \mathrm{~g} / \mathrm{mL}$ & 2.99 \\
\hline Total Beta & LSC & $1.82 \mathrm{E}+07 \mathrm{pCi} / \mathrm{mL}$ & 0.15 \\
\hline Total Solids & Measured & $22.55 \%$ & \\
\hline
\end{tabular}

a. Currently, a routine method for detecting this species does not exist in AD. 
The tank corrosion species listed in Table 3-9 were requested by Waste Solidification Engineering (WSE). ${ }^{*}$ Specific gravity was calculated by dividing the measured density of the slurry (given in Table $3-8$ at $19.1^{\circ} \mathrm{C}$ ) by the density of water at the same temperature $(0.9979$ $\mathrm{g} / \mathrm{mL}){ }^{8}$

Table 3-9. Requests from the WSE for Corrosion Species from Tank 50 Slurry Samples; Results Not Contained in Previous Tables.

\begin{tabular}{|l|c|c|c|}
\hline Constituent & Method & Average Concentration & \%RSD \\
\hline Specific Gravity & $\mathrm{a}$ & 1.1918 & 0.01 \\
\hline Ba-137m & $\mathrm{b}$ & $1.63 \mathrm{E}+07 \mathrm{pCi} / \mathrm{mL}$ & 0.52 \\
\hline Total Gamma & $\mathrm{b}$ & $1.47 \mathrm{E}+07 \mathrm{pCi} / \mathrm{mL}$ & 0.52 \\
\hline
\end{tabular}

a. Calculated from the measured density of slurry and density of water at $19.1{ }^{\circ} \mathrm{C}$

b. Calculated from the concentration of its radioactive parent Cs-137.

The radionuclide Ba-137m is the radioactive daughter of $94.6 \%$ of the beta decay of Cs-137. $5.3 \%$ of the Cs-137 decays to stable Ba-137. The half-life the parent radionuclide, Cs-137, is $5 \mathrm{x}$ that of the daughter, Ba-137m, therefore the two radionuclides are in secular equilibrium. Radionuclides in secular equilibrium have the same activity associated with decay. Thus the activity of Ba- $137 \mathrm{~m}$ is $94.6 \%$ of the activity of the Cs-137 or $1.63 \mathrm{E}+07 \mathrm{pCi} / \mathrm{mL}$. The activities calculated for total gamma and Ba-137m are expected to be close for this sample because the total gamma activity is dominated by Ba-137m, the radioactive daughter of Cs137. The total gamma activity was calculated by summing the measured gamma activity of the major gamma emitters: Co-60, Sb-125, Sn-126, Cs-137 (via Ba-137m), Eu-154, and Am241.

\footnotetext{
* Requested in an electronic mail message from S. D. Hevel on December 20, 2007. (See page 30 of WSRCNB-2007-00189.)
} 


\subsection{CONCLUSIONS}

The following conclusions are drawn from the analytical results provided in this report:

- The concentrations of the chemical and radioactive contaminants were all less than their respective WAC Targets or limits except Am-242m.

- The radionuclide Am-242m was not detected; however, its detection limit is above the WAC Target given in Attachment 8.4. The higher detection limit was expected based on current analytical capabilities as stated in the Task Technical and Quality Assurance Plan (TTQAP). ${ }^{3}$

- The reported detection limit of isopropanol is lower than its WAC Limit for accident analysis in Appendix 8.1 but higher than its WAC Concentration given in Table 4 in reference to vault flammability. The higher detection limit was expected based on current analytical capabilities and is documented in the Task Technical and Quality Assurance Plan (TTQAP). ${ }^{3}$

- The reported detection limit for Isopar L is lower than its WAC limit for accident analysis in Appendix 8.1 but higher than its WAC Concentration given in Table 3 in reference to vault flammability. The higher detection limit was expected based on current analytical capabilities as stated in the Task Technical and Quality Assurance Plan (TTQAP). ${ }^{3}$

- Isopar L and Norpar 13 have limited solubility in aqueous solutions making it difficult to obtain consistent and reliable sub-samples. The values reported in this memo are the concentrations in the sub-sample as detected by the GC/MS; however, the results may not accurately represent the concentrations of these analytes in Tank 50. 


\subsection{REFERENCES}

1. Ray, J. W., "Waste Acceptance Criteria for Aqueous Waste Sent to the Z-Area Saltstone Production Facility (U),” X-SD-Z-00001, Revision 8, December 2008.

2. Staub, A.V., “Technical Task Request,” HLW-SSF-TTR-2009-0002, Revision 0, November 2008.

3. DiPrete, C. C. and Bibler, N. E., "Task Technical and Quality Assurance Plan for the Tank 50 Waste Acceptance Criteria (WAC) Analyses”, SRNL-RP-2009-00600, Revision 0, May 2009.

4. Zeigler, K. E., and Bibler, N. E., "Analytical Study Plan for All Tank 50 Waste Acceptance Criteria (WAC) Quarterly Samples,” SRNL-ADD-2008-00026, Revision 0, February 2008.

5. Bibler, N. E, DiPrete, C. C., and Reigel, M. M., “Tables Containing Results for the First Quarter 2009 Tank 50 WAC Slurry Sample: Chemical and Radionuclide Contaminant Results,” SRNL-TR-2009-00342, Revision 0, September 2009.

6. Cozzi, A. D., "SRNL Support of TCLP Analysis for Tank DDA Samples, Task Technical and Quality Assurance Plan,” WSRC-TR-2007-00406, September 2007.

7. Zeigler, K. E., Bibler, N. E., and DiPrete, D. P., "Characterization of Tank 50 Slurry for Saltstone Waste Acceptance Criteria,” April 2007 Samples, WSRC-STI-200700554, November 2007.

8. Perry's Chemical Engineers' Handbook, 6th Edition, p 3-57, Editor D. W. Green, McGraw-Hill Book Co., NY, 1969. 


\subsection{ACKNOWLEDGEMENTS}

The authors wish to thank the following people of AD in SRNL for their assistance and helpful discussions, and quick turnaround with the results for these samples: Surjeet Bhutani, Leigh Brown, Steve Crump, David DiPrete, Susan Wells, Curtis Johnson, Mark Jones, Mira Malek, Jake Venzie, Kathy White, Tom White, and Boyd Wiedenman. We also acknowledge Alex Cozzi, and Erich Hansen for determining the density of the slurry and the weight percent total and insoluble solids. 


\section{Distribution:}

J.L. Adams, 704-14Z

A.B. Barnes, 999-W

M.J. Barnes, 773-A

C.H. Beheler, 704-14Z

N.E. Bibler, 773-A

P.L. Bovan, 704-27S

L.M. Chandler, 773-A

N.F. Chapman 766-H

A.D. Cozzi, 999-W

D.A. Crowley, 773-43A

C.C. DiPrete, 773-A

A.D. England, 704-14Z

S.D. Fink, 773-A

E.J. Freed 704-56H

C.W. Gardner, 773-A

B.J. Giddings, 786-5A

J.C. Griffin, 773-A

J.R. Harbour, 999-W

S.D. Heath, 704-Z

C.C. Herman, 999-W

P.J. Hill, 766-H

C.A. Langton, 773-43A

K.R. Liner, 704-S

M.J. Mahoney, 766-H

S.L. Marra, 773-A

D.J. Martin, 241-246H

D.J. McCabe, 773-42A

P.W. Norris, 704-Z

J.E. Occhipinti, 704-S

E. Patten, 704-Z

F.M. Pennebaker, 773-42A

J.W. Ray, 704-S

M.M. Reigel, 999-W

A.L. Richardson, 210-S

L.B. Romanowski, 766-H

A.R. Shafer, 704-27S

D.C. Sherburne, 704-S

A.V. Staub, 704-Z

A.W. Wiggins, 704-61H

R.H. Young, 773-A 